\title{
Kualitas Pendidikan dan Partisipasi Pekerja Indonesia Dalam Industri
}

\author{
Subijanto \\ Bagian Perencanaan Sekretariat Balitbang Kemdiknas
}

\begin{abstract}
Abstrak: Permasalahan perburuan/ketenagakerjaan di Indonesia belum mendapatkan perhatian dari Pemerintah, antara lain dalam hal pendidikan, pemberian jaminan kebebasan berserikat dalam menyatakan pendapat, kebijakan pengupahan, dan jaminan sosial pekerja yang kurang sesuai dengan kelayakan kebutuhan hidup minimal (KHM). Rendahnya tingkat pendidikan bangsa Indonesia tercermin antara lain dari Indeks Pembangunan Manusia (Human Development Index) tahun 2008 di mana Indonesia berada pada peringkat ke 109 dari 179 negara (nilai 0,726), peringkat tersebut terendah di Asia Tenggara. Di samping itu, sekitar 63, 35 \% struktur tenaga kerja Indonesia berpendidikan SD. Upaya mendorong pekerja melakukan hubungan industrial dapat dilakukan melalui organisaasi serikat pekerja (SP). Pengurus SP harus mau dan mampu memberi motivasi para anggotanya untuk berpartisipasi dalam hubungan industrial sesuai dengan bidang keahlian, potensi, dan minatnya. Melalui organisasi pembelajaran (learning organization) diharapkan para pekerja dapat meningkatkan pengetahuan dan keterampilannya, antara lain melalui program kesetaraan paket A, B, dan C yang layak untuk dilaksanakan oleh perusahaan.
\end{abstract}

Kata kunci: tingkat pendidikan, serikat pekerja, partisipasi, dan industri

\begin{abstract}
The main problem of the employee/worker asociation in Indonesia is the lack of concern from Indonesian Government, especial in term of the opportunity to have education, to protect guaranty fredom to have opinion, salary policy which is still under minimum wage. According to the Human Development Index in 2008 shows that the Indonesian rank of education is 109 to 179 countries (the value is 0,726 ), this rank means that Indonesian education rank is still under South East Asian. It is the fact that 63,35 \% the structure of Indonesian labor is graduate from primary level. The effort of the labor association's to push the participation of employee to be active in doing industrialization collaboration based on the competence in specific area, the potential and interest need. Hopefully, through learning organization every worker is able to improve their knowledge and skill ability by following equity program A, B, and C packages which can be done by industry
\end{abstract}

Key words: workers asociation, participation, and industry.

\section{Pendahuluan}

Sebagai Warga Negara Indonesia, setiap orang (termasuk pekerja/buruh) memiliki kemerdekaan untuk berkumpul, berserikat, dan berpendapat atau mengeluarkan pikiran, baik secara lisan maupun tulisan, memperoleh pekerjaan, dan penghidupan yang layak bagi kemanusiaan, serta mempunyai kedudukan yang sama dalam memperoleh perlakuan hukum. Oleh karena itu, dalam rangka mewujudkan kemerdekaan berserikat, pekerja/buruh berhak membentuk dan mengembangkan serikat pekerja/serikat buruh yang bebas, terbuka, mandiri, demokratis dan bertanggung jawab. Hal ini dimaksudkan untuk memperjuangkan, melindungi, dan membela kepentingan dan kesejahteraan pekerja/buruh beserta keluarganya, serta mewujudkan hubung- an industrial yang harmonis, dinamis, dan berkeadilan.

Hal tersebut dijamin oleh beberapa UndangUndang, antara lain: 1) Undang Undang Dasar Republik Indonesia Tahun 1945 (Pasal 5 ayat 1, Pasal 20 ayat 2) Pasal 27 dan Pasal 28 (UUD 1945 perubahan pertama tahun 1999); 2) Undang Undang Nomor:18 Tahun 1956 tentang Persetujuan Konvensi Organisasi Perburuhan Internasional: Hak untuk berorganisasi dan untuk berunding bersama; 3) Undang Undang Nomor: 39 Tahun 1999 tentang Hak Asasi Manusia; dan 4) Undang Undang Nomor: 21 Tahun 2000 tentang serikat pekerja/serikat buruh.

Serikat pekerja/serikat buruh dapat dijadikan sebagai wahana untuk para pekerja/buruh berpartisipasi dalam hubungan industrial sesuai 
dengan visi, misi, dan tujuan serta nilai-nilai dasar perjuangan organisasi/perusahaan. Melalui serikat pekerja/serikat buruh diharapkan setiap pekerja/buruh dapat termotivasi untuk berpartisipasi dalam hubungan industrial (industrial relation).

Tingkat pendidikan para pekerja/buruh sebagian besar masih didominasi oleh tamatan sekolah dasar. Sebagai pekerja, kesempatan memperoleh pendidikan formal mupun non formal sangat terbatas dan bahkan dapat dikatakan cenderung jarang diberi kepada para pekerja/ buruh untuk meningkatkan pengetahuan dan keterampilannya. Pelatihan teknis atau keterampilan yang mendukung keterampilannya pun dapat dikatakan jarang terjadi secara terprogram, bertahap dan berkesinambungan. Padahal, setiap pekerja/buruh masih memiliki kesempatan untuk mendapatkan pendidikan minimal wajib belajar 9 tahun (minimal tamat SMP) di samping hak untuk meneruskan pendidikannya ke jenjang yang lebih tinggi sesuai dengan bakat dan minatnya.

Kondisi ini didukung dangan data yang menunjukkan bahwa tingkat pendidikan para tenaga kerja/buruh di Indonesia sebagaimana yang dikemukakan Siswo Wiratno (2009) bahwa sekitar 63, $35 \%$ struktur tenaga kerja Indonesia berpendidikan SD dan secara keseluruhan kualitas sumber daya manusia (SDM) masih tergolong rendah. Meskipun tingkat melek huruf di Indonesia telah cukup tinggi, namun jumlah penduduk yang telah menyelesaikan pendidikan di atas sekolah dasar masih rendah. Rendahnya tingkat pendidikan di Indonesia tercermin antara lain dari Indeks Pembangunan Manusia (Human Development Index) tahun 2008 di mana Indonesia berada pada peringkat ke 109 dari 179 negara (nilai $0,726)$, peringkat tersebut terrendah di Asia Tenggara (Anonim, HDI update 2008 Indonesia).

Laporan Mendiknas (saat itu Malik Fajar) disampaikan tanggal 31 Januari 2002 antara lain menyatakan bahwa salah satu indikator bahwa kualitas SDM Idonesia rendah tercermin pada data yang menunjukkan bahwa $78,8 \%$ tidak tamat sekolah dasar (SD), 10,72 \% tamat SMP dan 10,69 $\%$ tamat SLTA, bahkan diasumsikan sampai saat ini kondisi tersebut relatif belum ada perubahan yang cukup signifikan ke arah perkembangan yang proporsional.
Tingginya tingkat pengangguran tersebut menunjukkan lemahnya pengembangan sumber daya manusia (SDM) dan sistem pendidikan yang belum mampu menghasilkan lulusan yang bermutu dan produktif bagi pertumbuhan ekonomi. Relevansi pendidikan bagi dunia kerja dan masyarakat perlu mendapat perhatian yang serius. Hal ini antara lain disebabkan pengelolaan pendidikan selama ini diibaratkan sebagai lokomotif yang dijalankan secara birokratik dan sentralistik. Diharapkan keselarasan antara dunia pendidikan dengan dunia kerja akan semakin terwujud melalui berbagai program dan kebijakan yang bersinergi antara Kementerian Pendidikan Nasional dengan Kementerian Tenaga Kerja sebagai lini terdepan dalam upaya menyiapkan tenaga kerja yang dapat mengisi kebutuhan tenaga kerja yang memiliki kompetensi dan daya saing yang sepadan dengan kebutuhan dunia kerja di masa mendatang.

Permasalahan perburuan di Indonesia dapat diasumsikan merupakan masalah yang akut yang dibiarkan sampai menumpuk tanpa diimbangi dengan upaya nyata untuk menuntaskan pemecahannya secara tuntas. Ketenagakerjaan di Indonesia belum mendapatkan perhatian yang proporsional oleh Pemerintah, terutama dari aspek pemberian jaminan kebebasan berserikat dalam menyatakan pendapat bagi pekerja, kebijakan memperoleh pendidikan wajib belajar dan pendidikan lanjutan, kebijakan pengupahan, dan jaminan sosial pekerja yang kurang sesuai dengan kelayakan kebutuhan hidup minimal (KHM) dan lembaga peraadilan perburuhan. Di samping itu, para pengurus serikat pekerja/serikat buruh pada umumnya bukan berasal dari organisasi serikat pekerja/serikat buruh, sehingga berbagai kebijakan dirasa kurang berpihak pada serikat pekerja/serikat buruh.

Tujuan dari penulisan artikel ini adalah memberikan sumbang saran pemikiran untuk meningkatkan pendidikan dan pelatihan serta meminimalis kekurang harmonisan antara pekerja dan majikan melalui sarana organisasi serikat pekerja/serikat buruh sehingga tercipta budaya organisasi yang berdampak pada peningkatan produktivitas kerja. 
Kajian Literatur dan Pembahasan Hak memperoleh pendidikan

Pada hakikatnya setiap manusia memerlukan pendidikan dalam pengembangan potensi dirinya sehingga ia dapat tumbuh dan berkembang sesuai dengan tingkat perkembangan usia, bakat, minat, dan kecerdasannya. Pentingnya aspek pendidikan sebagaimana tersurat dalam Pembukaan UndangUndang Dasar Negara Republik Indonesia Tahun 1945 pada alinea ketiga dinyatakan bahwa Pemerintah berkewajiban untuk mencerdaskan kehidupan bangsa. Lebih lanjut, Pasal 31 ayat (1) UUD 1945 dinyatakan bahwa: "Setiap warga negara berhak mendapat pendidikan" dan ayat (2) "Setiap warga negara wajib mengikuti pendidikan dasar dan pemerintah wajib membiayainya".

Mengacu pada kedua ayat tersebut, secara yuridis formal, setiap Warga Negara Indonesia memiliki hak yang sama untuk memperoleh pendidikan. Hal itu diperkuat dengan Pasal $28 \mathrm{C}$ ayat (1) UUD 1945 tentang Hak Asasi Manusia, di mana disebutkan bahwa "Setiap orang berhak mengembangkan diri melalui pemenuhan kebutuhan dasarnya, berhak mendapat pendidikan dan memperoleh manfaat dari ilmu pengetahuan dan teknologi, seni dan budaya, demi meningkatkan kualitas hidupnya dan demi kesejahteraan umat manusia". Lebih khusus lagi, hak warga negara yang berkaitan dengan Hak Asasi Manusia (HAM) sebagaimana termaktub dalam Pasal 12 UndangUndang Nomor 39 Tahun 1999 tentang HAM dengan tegas dinyatakan bahwa "Setiap orang berhak atas perlindungan bagi pengembangan pribadinya, untuk memperoleh pendidikan, mencerdaskan dirinya, dan meningkatkan kualitas hidupnya agar menjadi manusia yang beriman, bertaqwa, bertanggungjawab, berakhlak mulia, bahagia, dan sejahtera sesuai dengan hak asasi manusia". Pasal lain yang mendukung hak tersebut yaitu dalam Pasal 60 ayat (1) UU HAM Nomor 39/1999 disebutkan bahwa "Setiap anak berhak untuk memperoleh pendidikan dan pengajaran dalam rangka pengembangan pribadinya sesuai dengan minat, bakat, dan tingkat kecerdasannya". Di samping ke dua UU tersebut, UU yang erat kaitannya dengan penyelenggaraan pendidikan adalah UndangUndang Nomor: 20 Tahun 2003 tentang Sistem Pendidikan Nasional Pasal 4 ayat (1), di mana disebutkan bahwa "Pendidikan diseleng-garakan secara demokratis dan berkeadilan serta tidak diskriminatif dengan menjunjung tinggi hak asasi manusia, nilai keagamaan, nilai kultural, dan kemajemukan bangsa". Selanjutnya, dalam Pasal 5 ayat (1) disebutkan pula bahwa "Setiap warga negara mempunyai hak yang sama untuk memperoleh pendidikan yang bermutu". Dalam hal pemberian layanan dan kemudahan pendidikan kepada setiap warga negara ditegaskan dalam Pasal 11 ayat (1) di mana "Pemerintah dan pemerintah daerah wajib memberikan layanan dan kemudahan, serta menjamin terselenggaranya pendidikan yang bermutu bagi setiap warga negara tanpa diskriminasi". Analog dengan penyelenggara pendidikan oleh Pemerintah dan pemerintah daerah, maka penyelenggaraan pendidikan di berbagai jenis, jenjang dan jalur pendidikan di Indonesia yang diselenggarakana oleh masyarakat wajib hukumnya untuk mengacu pada landasan yuridis sebagaimana yang telah penulis uraikan di atas.

\section{Pendidikan dan Pelatihan}

Pendidikan dan pelatihan (diklat) merupakan salah satu cara untuk meningkatkan kualitas sumber daya manusia (SDM). Pada hakikatnya, pendidikan dan pelatihan merupakan bagian dari investasi sumber daya manusia (human investment) untuk meningkatkan kemampuan dan keterampilan kerja.

Secara empirik, pendidikan menjadi tanggungjawab Kementerian Pendidikan Nasional (Kemdiknas) dan pelatihan menjadi tanggungjawab Kementerian Tenaga Kerja dan Transmigrasi (Kemnakertrans). Kedua kementerian tersebut sampai saat ini diasumsikan belum memiliki kesepakatan yang sama terkait dengan upaya peningkatan kualitas SDM. Seharusnya, bidang garap pendidikan memiliki garis demarkasi yang jelas dengan bidang garap pelatihan, dan keduanya saling ada keterkitan dan kesepadanan (link and match) antara kompetensi yang dicapai melalui pendidikan dan kompetensi yang diperoleh melalui pelatihan di dunia usaha dan dunia industri (DUDI). Pendidikan sistem ganda (dual system) di mana pendidikan teori dilakukan di sekolah dan praktik dilakukan di industri merupakan salah satu cara untuk mewujudkan mutu dan 
relevansi antara pendidikan dan kebutuhan dunia kerja. Pelaksanaan pendidikan sistem ganda yang memadukan tercapainya kompetensi tamatan dengan kebutuhan dunia kerja meruapan salah satu cara yang mendekat-kan antara kompetensi calon tenaga kerja dengan kebutuhan DUDI. Hal ini sekaligus mengurangi kesan masyarakat industri yang beranggapan bahwa tamatan satuan pendidikan sebagai calon tenaga kerja tingkat dasar dan menengah memiliki sikap, disiplin, kemampuan intelektual, dan keterampilan yang serba serba tanggung. Sebagai salah satu dampak yang kurang menguntungkan terhadap calon tenaga kerja dari satuan pendidikan dasar menunjukkan adanya beberapa perusahaan (khususnya penyalur tenaga kerja) cenderung menerima karyawan apa adanya, dan bahkan ada yang lebih ekstrim lagi menerima calon tenaga kerja tanpa memiliki keterampilan fungsional yang memadai sehigga adai lapangan banyak dijumpai hal-hal yang tidak sesuai dengan hak dan kewajiban tenaga kerja.

Kualitas pendidikan untuk pemenuhan kebutuhan tenaga kerja Indonesia di luar negeri (terutama tenaga kerja weanita) memang belum memperoleh perhatian secara khusus. Kebutuhan akan tenaga kerja wanita yang memiliki kompetensi sesuai kebutuhan lapangan pada umumnya belum memenuhi persyaratan, Namun demikian, upaya untuk memenuhi kebutuhan tenaga kerja luar negeri dirasa perlu untuk dilakukan kerjasama secara sinergi dan koordinasi yang intensif dari berbagai instansi yang berkepentingan (stakeholdes).

\section{Pengertian Hubungan Industrial (Partisipasi Pekerja) dan implikasi di lapangan.}

Hubungan industrial atau hubungan perburuan pada hakikatnya merupakan hubungan antar pihak-pihak terkait dengan kepentingan, yaitu antara pekerja (buruh) dan pengusaha (majikan), serta organisasi buruh (serikat pekerja) dan organisasi pengusaha (organisasi majikan) itu sendiri. Secara harfiah "buruh" dimaknai sebagai orang yang bekerja di bawah perintah orang lain, di mana ia menerima upah karena melakukan pekerjaan di tempat ia bekerja (perusahaan, pabrik/industri). Istilah "buruh" di mata masyarakat Indonesia nampaknya masih terkesan "negative" di mana istilah tersebut kurang menguntungkan dengan beberapa alasan sebagai penyertanya.

Pertama, ada "buruh" berarti ada "majikan", sehingga menimbulkan kesenjangan yang tidak setara dan menimbulkan polarisasi "kasta" atau "kelas" (golongan status sosial) yang berbeda kepentingan. Kedua, kata "buruh" menimbulkan konotasi sebagai kelompok tenaga kerja dari golongan bawah yang bekerja dengan hanya mengandalkan kekuatan fisik (otot), bukan mengandalkan pemikiran (daya nalar) atau keterampilan/kompetensi. Ketiga, masih ada kesan di masyarakat terhadap kata "buruh" teringat dengan ajaran "marxisme" atau setidaktidaknya dengan gerakan 30 September, di mana saat itu buruh tani sebagai "Barisan Tani Indonesia" atau BTI sebagai salah satu organisasi "onderbow" PKI. Disamping itu, buruh dianggap sebagai kelompok kelas yang dapat dieksploitisir oleh majikan sebagai budak (dieksploitasi sebagai perbudakan) dengan tidak mengindahkan hak-hak asasi manusia. Bahkan sampai saat ini, buruh masih dianggap sebagai kelompok yang selalu berusaha menghancurkan "majikan/pengusaha" dalam memperjuangkan hak-haknya (dalam bentuk demonstrasi dan anarki).

Pemikiran yang cukup netral terhadap istilah "buruh" bilamana kata "buruh" diganti dengan kata "pekerja" sekalipun masih terdapat istilah lainnya seperti "pegawai" atau "karyawan". Istilah pegawai telah melekat dimiliki oleh seseorang yang bekerja di instansi pemerintah (sebut PNS), sedangkan "karyawan" dapat dimaknai sebagai orang yang melakukan karya atau berkarya di berbagai bidang pekerjaan di suatu perusahaan/industri. Istilah karyawan lebih bersifat umum, sehingga masyarakat mengenalnya dengan sebutan karyawan buruh, karyawan pengusaha, karyawan ABRI, dan sebagainya.

Secara empirik, istilah "pekerja" semestinya lebih luas, yaitu orang yang melakukan pekerjaan, baik dalam hubungan kerja maupun di luar kerja. Istilah "buruh" terasa kurang proporsional pada zaman penjajahan, yaitu orang yang melakukan pekerjaan kasar, misalnya kuli angkut barang, tukang batu, montir mobil, dll. Kelompok buruh ini dikenal dengan sebutan pekerja yang kerah bajunya berwarna biru-gelap (b/ue collar), 
sebaliknya, untuk kelompok kerja perkantoran (bidang administrasi) yang bekerja di belakang meja, dikenal dengan sebutan "white collar". Secara psikologis, pergantian istilah "buruh" diganti "pekerja" menimbulkan kesan yang lebih netral dalam memanusiakan manusia.

Hal ini sejalan dengan pedoman pelaksanaan Hubungan Industrial Pancasila, yang mencakup: 1) Pengusaha, istilah "pengusaha" digunakan sebagai pengganti istilah "majikan". Majikan pada umumnya dikaitkan dengan kelompok "buruh". Istilah "pengusaha" dirasa lebih mencerminkan kedudukan dalam hubungan industrial Pancasila. Secara definitif, pengusaha adalah orang yang memiliki otoritas mempekerjakan pekerja dengan memberi imbalan upah kerja pada pekerjanya; 2) Serikat pekerja (Iobor union), pada hakikatnya antara pekerja dan pengusaha bukanlah dua kubu kekuatan yang memiliki perbedan kepentingan, sehingga saling berusaha untuk memenangkan kepentingannya dengan kekuatan tertentu. Namun demikian, justru keduanya saling membutuhkan dan bekerja sama untuk dapat mencapai tujuan yang sama yaitu kesejahteraan bersama. Salah satu perwujudan upaya tersebut adalah mendirikan suatu organisasi pekerja yang diberi nama "Serikat Pekerja". Serikat Pekerja sekaligus sebagai pengganti "Serikat Buruh" dan hal ini sesuai dengan UUD 1945 (Penjelasan Pasal 2) yang menyatakan bahwa "yang disebut golongan-golongan ialah Badan-badan seperti koperasi, serikat pekerja dan lain-lain badan kolektif".

Hubungan Industrial Pancasila seharusnya disosialisasikan kepada para anggota "Serikat Pekerja" secara bertahap dan berkesinambungan. Hal ini perlu mendapat perhatian khusus karena hal itu dapat menciptakan suasana kerja yang dapat menumbuh kembangkan suasana kekeluargaan, kegotong-royongan, dan musyawarah untuk mufakat dalam aktivitas dan perolehan hak-haknya di perusahaan.

Serikat Pekerja/Buruh merupakan serikat atau asosiasi para pekerja untuk jangka waktu yang cukup lama dan berlangsung secara terusmenerus dibentuk dan diselenggarakan dengan tujuan memajukan/mengembangkan kerjasama dan tanggung jawab bersama, baik antara para pekerja, maupun antara pekerja dengan pengu- saha. Dengan demikian, tujuan pendirian 'Serikat Pekerja" bersifat intern (dalam rangka memajukan dan mengembangkan kerjasama dan tanggung jawab para anggota serikat pekerja) dan ekstern (dalam hubungan kerja sama dan tanggung jawab terhadap pengusaha maupun lingkungan lainnya).

\section{Teori hubungan industrial}

Beberapa teori yang terkait dengan serikat buruh, antara lain: pertama, Teori Kemakmuran Umum, teori ini cenderung mengarah pada pemahaman bahwa apa yang baik bagi Serikat Pekerja/Serikat Buruh baik pula untuk kepentingan bangsa. Upah tenaga kerja yang tinggi merupakan sumber tenaga beli yanga mendorong dan memperkuat pertumbuhan ekonomi. Hal ini berakibat pada setiap kenaikan upah akan mendorong ke arah ekspansi dan pertumbuhan. Perlindungan Serikat Pekerja yang diberikan kepada para anggotanya terhadap tindakan sewenang-wenang para majikan/pengusaha diidentifikasikan dengan kemajuan ekonomi. Begitu pula tuntutan jaminan sosial dan kesehatan oleh serikat-serikat pekerja dipandang sebagai suatu tuntutan yang akan memeberi manfaat bagi mereka yang berada di luar Serikat Pekerja (Anonim, tanpa tahun).

Kedua, Teori Labor Marketing, teori ini cenderung mengarah pada pernyataan bahwa pada umumnya kondisi di tempat pekerja/buruh bekerja ditentukan oleh kekuatan dan pengaruh buruh di pasar dengan tenaga kerja. Serikat Pekerja mengganggap dirinya sebagai "economist agent" di bursa tenaga kerja. Manakala persediaan tenaga kerja lebih besar dari permintaan (demand) maka harga tenaga kerja akan murah, dan begitu sebaliknya (Anonim, tanpa tahun).

Ketiga, Teori Produktivitas, di mana hal ini produktivitas kerja sangat menentukan besar kecilnya upah pekerja/buruh di suatu perusahaan. Semakin produktif karyawan dalam menyelesaikan pekerjaan akan emakin tinggi upah yang diterimanya (Anonim, tanpa tahun).

Keempat, Teori Bargaining, di mana tingkat upah pekerja/buruh di tingkat pasar tenaga kerja sangat dipenagruhi oleh kekuatan ekonomi yang berlawanan dari pekerja dan majikan. Apabila buruh meningkatkan ekonominya dengan cara bertindak bersama-sama melalui serikat pekerja/ buruh sebagai bargaining agent, maka mereka 
dapat meningkatkan upah mereka (Anonim, tanpa tahun).

Kelima, Oposisi Loyal terhadap manajemen, Serikat pekerja/buruh berpendapat bahwa fungsi manajemenadalah mengelola, sedangkan Serikat Pekerja/Buruh mempunyai tanggung jawab pengawasan/pengendalian atas kualitas manajemen (Anonim, tanpa tahun).

Dengan tanggung jawab ini, manajemen dipaksa untuk selalu berusaha bekerja sebaik mungkin terutama bidang pengunaan tenaga kerja. Namun demikian, teori ini tidak mensyaratkan Serikat Pekerja/Serikat Buruh sebagai manajer, akan tetapi justru menganjurkan Serikat Pekerja/Serikat Buruh menolak tanggung jawab atas manajemen.

\section{Aspek legal formal}

Politik perburuhan di Indonesia masih belum tertata dengan acuan yang memberikan ramburambu dalam berorganiasasi secara profesional. Pada waktu B.J Habibie sebagai Presiden RI, telah mengeluarkan UU tentang Ketenagakerjaan Nomor 25/1997 yang saat ini telah diperbaharui melalui UU Nomor 13/2003. Namun, UU Nomor 21/ 2000 mengatur khusus tentang Serikat Pekerja/ Serikat Buruh yang dalam implementasinya masih belum berpihak kepada para pekerja/buruh khususnya manakala terjadi perselisihan kepentingan. Hal ini ditunjukkan beberapa kasus di PT Kong Tai Indonesia (KTI) dan beberapa kasus di perusahaan lainnya yang berakibat pada dilakukannya pemutusan hubungan kerja (PHK).

Dari aspek legal formal, sampai saat ini belum ada undang-undang khusus tentang perlindungan pekerja/buruh yang berpihak kepada kepentingan pekerja/buruh. Lebih lanjut, implementasi UU yang ada seperti UU HAM No. 39/1999; UU RI Tahun 1984 (ratifikasi konvensi Penghapusan Segala Bentuk Diskriminasi terhadap perempuan/CEDAW: Pasal: 2, 6, 9, 11, 12, 14, 15, dan 16); UU RI No.20/1999 (ratifikasi konvensi ILO No. 38 tentang usia minimum yang diperbolehkan bekerja; Ratifikasi 1990 tentang Perlindungan buruh migran dan keluarganya; Keppres No.36/1990 (ratifikasi Konvensi Hak Anak), UU Nomor 21/2000 tentang Serikat Pekerja/ Serikat Buruh, dan UU Nomor 13/2003 tentang Ketenagakerjaan, dsb. Namun, dalam kenyataan- nya belum dapat menangani berbagai kasus ketenagakerjaan secara utuh dan tuntas (http:// www. hukumonline.com/detail.asp?id $=18838 \& \mathrm{cl}=$ Berita).

\section{Organisasi Pekerja dan Pengusaha Serikat Pekerja/Serikat Buruh}

Secara yuridis formal, batasan pekerja/buruh secara jelas diungkapkan dalam Pasal 1 angka 2 UU Nomor 13/2003 tentang ketenagakerjaan, yaitu bahwa "Pekerja/buruh adalah setiap orang yang bekerja dengan menerima upah atau imbalan dalam bentuk lain". Selanjutnya, batasan Serikat Pekerja/Serikat Buruh sebagaimana dimaksud dalam Pasal 1 angka 1 UU Nomor 21/2003 adalah bahwa "Serikat Pekerja/Buruh adalah organisasi yang dibentuk dari, oleh, dan untuk pekerja/buruh baik di perusahaan maupun di luar perusahaan, yang bersifat bebas, terbuka, mandiri, demokratis, dan bertanggung jawab guna memperjuangkan, membela serta melindungi hak dan kepentingan pekerja serta meningkatkan kesejahteraan pekerja/buruh dan keluarganya". Atas dasar batasan itu, maka tertutup kemungkinan seseorang yang bukan pekerja/buruh dapat menjadi anggota atau apalagi sebagai pemimpin Serikat Pekerja/Serikat Buruh dimaksud.

Untuk menyalurkan partisipasi pekerja/buruh dalam industri, dapat dibentuk Serikat Pekerja/ Serikat Buruh sebagai wahana untuk menyampaikan berbagai aspirasi dalam mewujudkan partisipasi industri melalui organisasi/perusahaan. Pembentukan Serikat Pekerja atau asosiasi para pekerja dapat direncanakan jangka waktu yang cukup lama dan berlangsung secara terusmenerus dibentuk dan diselenggarakan dengan tujuan memajukan/mengembangkan kerjasama dan tanggung jawab bersama, baik antara para pekerja, maupun antara pekerja dengan pengusaha. Dengan demikian, tujuan pendirian 'Serikat Pekerja" bersifat intern (dalam rangka memajukan dan mengembangkan kerjasama dan tanggung jawab para anggota serikat pekerja) dan ekstern (dalam hubungan kerja sama dan tanggung jawab terhadap pengusaha maupun lingkungan lainnya). Selanjutnya, Serikat Pekerja/ Serikat Buruh (SP/SB) dapat dibentuk di satu atau lebih perusahaan dan dapat digabung menjadi suatu Federasi. Hal ini sejalan dengan UU Nomor 
$21 / 2000$ yang menyebutkan bahwa tujuan pendirian SP/SB, federasi dan konfederasi SP/SB adalah untuk memberikan perlindungan, pembelaan hak dan kepentingan, serta meningkatkan kesejahteraan yang layak bagi pekerja/ buruh dan keluarganya (Pasal 4).

Hak berserikat atau berorganisasi dipandang sebagai suatu kebutuhan mutlak yang harus dipenuhi sebagai sarana memperjuangkan terpenuhinya hak-hak pekerja/buruh seperti hak atas upah, hak pekerja/buruh perempuan atas fungsi reproduksi dan hak atas kesehatan dan keselamatan kerja (http://www. (ppi) (ppiindia), Pentingnya Serikat Buruh). Esensi pembentukan Serikat Pekerja/Serikat Buruh ditegaskan dalam UU Nomor 21/2000 tentang Serikat Pekerja/ Serikat Buruh. Secara eksplisit konsideran UU tersebut menyebutkan bahwa serikat/pekerja/ serikat buruh merupakan sarana untuk memperjuangkan, melindungi, dan membela kepentingan dan kesejahteraan pekerja/buruh beserta keluarganya, serta mewujudkan hubungan industrial yang harmonis, dinamis, dan berkeadilan (Anonim, tanpa tahun).

Selanjutnya, dalam ketentuan Pasal 110 ayat (1), (2), dan (3) menyebutkan bahwa peraturan perusahaan disusun dengan memperhatikan saran dan pertimbangan dari wakil pekerja/buruh. Dalam hal ini di perusahaan-perusahaan telah terbentuk serikat-serikat pekerja/serikat-serikat buruh otomatis notabene mewakili sebagai pengurus perserikatan. Dalam menajalankan sebagai fungsinya, serikat pekerja/serikat buruh dituntut untuk beperan aktif manakala terjadi perselisihan antara buruh dan pengusaha, dengan tetap berdiri di atas kepentingan pekerja/ buruh. Namun demikian, sebagaimana dimaksud dalam Pasal 151 ayat (1) dan ayat (2) UU Nomor $13 / 2003$ pada intinya diharapkan agar pengusaha tidak melakukan pemutusan hubungan kerja (PHK) manakala terjadi perselisihan yang berkepanjangan.

\section{Asosiasi Pengusaha Indonesia (APINDO)}

Asosiasi Pengusaha Indonesia merupakan organisasi para pengusaha Indonesia atau disingkat APINDO. Organisasi ini merupakan wadah kesatuan para pengusaha yang ikut serta untuk mewujudkan kesejahteraan sosial dalam usahanya melalui kerjasama yang terpadu dan serasi antara Pemrintah, pengusaha dan pekerja. APINDO berbentuk badan hukum, bersifat demokratis, dengan lingkup kegiatan sosialekonomi, khususnya di bidang hubungan industrial dan ketenagakerjaan.

Beberapa hal terkait dengan tujuan organisasi sesuai dengan Anggaran Dasar (AD) Pasal 7, menyebutkan antara lain bahwa: 1) Menciptakan dan memelihara keseimbangan, ketenangan, dan kegairahan kerja dalam lapangan hubungan perburuhan dan ketenagakerjaan, 2) Mengusahakan peningkatan produktivitas kerja sebagai peran serta akktif untuk mewujudkan pembangunan nasional menuju kesejahteraan sosial, spiritual, dan material, serta 3) Menciptakan adanya kesatuan pendapat dalam melaksanakan kebijaksanaan perburuhan dari para pengusaha yang disesuaikan dengan kebijaksanaan Pemerintah.

Lebih lanjut, dalam Anggaran Rumah Tangga (ART) Pasal 8 lebih rinci memuat hal-hal yang antara lain berkaitan dengan kerjasama, baik internal organisasi (pekerja dan pengusaha), pemerintah, maupun organisasi swasta, melakukan pendidikan dan pelatihan bagi para anggotanya, menyelesaikan permasalahan, pembentukan badan-badan di daerah, memberikan saraan kepada pemerintah, pembinaan anggota, membentuk forum diskusi, dsb. Hal tersebut mengindikasikan bahwa APINDO mendorong dan memberikan kesempatan kepada para pekerja dan pengusaha untuk berpartisipasi secara aktif dalam hubungan industrial Pancasila sesuai dengan bidang keahliannya masing-masing.

\section{Organisasi Buruh Internasional (International Labor Organization)}

Organisasi ini didirikan pada tahun 1919, setahun setelah Perang Dunia I berakhir. International Labor Organization (ILO) bertujuan untuk memperbaiki kondisi para pekerja sebagai upaya mewujudkan keadilan sosial di seluruh dunia. Untuk mencapai tujuan tersebut, ILO mengadopsi struktur tripartit yang khas, yaitu terdiri atas perwakilan pemerintah, pekerja, dan pengusaha. Ketiga unsur tersebut secara bersama-sama bertugas merencanakan strategi dan cara yang terbaik untuk mencapai tujuan ILO. 
Kebijakan ILO dalam kemitraan diberikan dalam bentuk bantuan khusus yang diberikan kepada serikat pekerja/buruh dalam kerangka kemitraan aktif. Prioritas dan kemitraan aktif adalah pemberian bantuan dan advokasi teknis dalam penerapan standar perburuhan internasional, khusunya konvensi dasar ILO tentang pokokpokok HAM. Tim multidisipliner ini terdiri atas pakar-pakar kegiatan pekerja/buruh. Tim ini bertanggung jawab mendorong partisipasi serikat pekerja/serikat buruh dalam kegiatan-kegiatan ILO dan memastikan bahwa program dan proyek yang dijalankan sesuai dengan kebutuhan serikat/pekerja secara efektif.

Biro pendidikan Pekerja (ACTRAV) merupakan suatu unit khusus di $I L O$, berfungsi untuk memelihara jaringan/hubungan antarserikat pekerja/buruh di negara-negara anggota, menempatkan sumber daya yang dimiliki ILO untuk kepentingan serikat pekerja/buruh dan untuk menjaga agar ILO tetap berhubungan dekat dengan agenda, prioritas, kepentingan, dan pandangan dari serikat pekerja/buruh (Anonim, tanpa tahun).

Skala prioritas ACTRAV adalah mempromosikan: a) pengembangan dan penguasaan organisasi serikat pekerja/buruh yang representatif, independen, dan demokratis, b) penguatan kapasitas organisasi serikat pekerja/buruh untuk terlibat dalam pengambilan keputusan di level legal, sosial, dan ekonomi, c) forum koordinasi bagi semua kegiatan, program, dan proyek ILO agar sesuai dengan kebutuhan serikat pekerja/buruh, dan d) partisipasi aktif pekerja/buruh dalam kegiatan-kegiatan ILO.

Di samping itu, ACTRAV juga menyediakan bantuan teknis untuk serikat pekreja/buruh melalui program konsultasi/advisori dan pelatihan, seperti seminar dan kursus-kursus dalam bidang: 1) Standar legislasi dan standar perburuhan internasional; 2) Hubungan internasional dan perundingan bersama (collective bargaining); 3) Kebijakan ketenagakerjaan; 4) Jaminan sosial; 5) Keselamatan dan kesehatan kerja dan lingkungan kerja; 6) Persamaan kesempatan dan gerakan antidiskriminasi; 7) Metode pelatihan dan belajar jarak jauh yang modern; dan 8) Manajemen dan administrasi serikat pekerja/buruh (Anonim, tanpa tahun).
Dengan demikian, dapat dikatakan bahwa ILO memberikan kesempatan kepada negara-negara anggotanya untuk bersama-sama berpartisipasi dalam mewujudkan program dan kegiatan ILO serta memberi kesempatan kepada serikat pekerja/buruh untuk mendorong anggotanya mengkuti berbagai kesempatan mengikuti program-program ILO yang telah ditetapkan (http://survey07.ituc-csi.0rg/getcountry.pnp? IDLang $=$ EN\&IDCountry $=$ IDN\&ID Supp $=\ldots 18 / 10 /$ 2008).

\section{Gerakan Pekerja/Buruh di Indonesia}

Proses industrialisasi merupakan wahana tumbuh dan berkembangnya organisasi buruh. Organisasi ini berusaha untuk mempengaruhi dan memperjuangkan kondisi para pekerja, kebijakan, dan praktik manajemen serta kebijakan Pemerintah mengenai kondisi, persyaratan kerja, dan hubungan kerja (Anonim, tanpa tahun). Di Amerika dan Eropa misalnya, para pengusaha membentuk organisaasi untuk mengimbangi dan membatasi pengaruh organisasi buruh.

Istilah gerakan buruh secara umum meliputi berbagai macam asosiasi yang timbul dalam kondisi ekonomi industri. Gerakan buruh merupakan seluruh aktivitas para penerima upah (buruh) untuk memperbaiki kondisi kerja mereka (The Encyclopedia of Social Science). Serikat buruh atau serikat pekerja adalah asosiasi para penerima upah (buruh) yang bersifat sukarela dan berkesinambungan dan memiliki tujuan jangka panjang untuk melindiungi para anggotanya dalam hubungan kerja maupun meningkatkan taraf hidup mereka. Lebih lanjut, sebagaimana dikatakan oleh tokoh perburuhan seperti Kerr, Dunlop, Herbison, dan Myers menyimpulkan bahwa industrialisasi menciptakan berbagai macam organisasi kaum buruh, sekalipun beda fungsi, struktur kepemimpinan, dan ideologi. Kondisi tersebut menyebabkan ketidak seimbangan para pekerja, sehingga tujuan gerakan buruh berubah-ubah dari waktu ke waktu.

Keberadaan serikat pekerja/serikat buruh mempunyai pengaruh yang sangat signifikan dalam dunia ketenagakerjaan di Indonesia. Hal ini terbukti dengan berbagai kebijakan Pemerintah, selalu direspon dengan beragam tanggapan/reaksi dari serikat-serikat pekerja/ 
buruh. Namun, yang cukup diwaspadai adalah pada akhir-akhir ini gerakan Serikat Pekerja seringkali terjebak dalam suasana kemelut muatan politik sehingga meninggalkan nilai-nilai dasar perjuangan organisasi/asosiasi Serikat pekerja itu sendiri. Hal ini layak diduga bahwa telah terjadi fenomena semakin banyaknya pemimpin serikat pekerja yang pada kenyataannya bukan berasal dari pekerja/buruh itu sendiri. Hal itu dirasa jelas kurang menguntungkan bagi para pekerja karena mereka kurang menghayati hak-hak pekerja, perlakuan yang kurang menguntungkan bagi pekerja, dan nasib pekerja di Indonesia pada umumnya. Sementara itu, manakala terjadi perundingan "tripartrit" yang membahas isu-isu perburuhan/ketenagakerjaan diwakili oleh orang-orang yang bukan dari unsur pekerja, sehingga jarang sekali hasil perundingan tersebut berpihak kepada kaum buruh/pekerja.

Permasalahan perburuan di Indonesia merupakan masalah yang parah yang dibiarkan sampai menumpuk tanpa ada upaya untuk menuntaskan pemecahananya. Sebaliknya, di kalangan masyarakat dan serikat pekerja/serikat buruh belum tumbuh kesadaran yang berkembang terhadap budaya berorganisasi (labor union) yang sehat dan sportif serta dewasa dan bebas dari muatan politik, akibatnya pendewasaan kepribadian kurang sehingga muncul radikalisme tuntutan yang berlebihan dan sering tanpa membawa hasil (Suara Federasi Serikat Pekerja BUMN Bersatu).

Oleh karena itu, dalam mendorong para pekerja/buruh berpartisipasi aktif dan berkontribusi pada sasaran kegiatan industri diharapkan pengurus seerikat pekerja/serikat buruh mau dan mampu melakukan advokasi dan memberikan motivasi kepada setiap anggotanya agar manajemen kinerja perusahaan selalu meningkat dari waktu ke waktu. Untuk itu, diperlukan upaya konkrit dalam bentuk pembinaan dan bimbingan teknis yang dapat menciptakan saling pengertian (mutual understanding) dan saling menguntungkan (mutual benefit) bagi kedua belah pihak (pekerja dan pengusaha). Dengan demikian, diharapkan dapat tercipta iklim kerja yang aman, nyaman, dan menyenangkan serta dalam koridor yang kondusif sehingga manajemen kinerja dapat meningkat. Untuk mewujudkan hal tersebut salah satu upaya dapat dilakukan melalui pendidikan dan pelatihan yang terkait dengan kualitas pendidikan bagi tenaga kerja di Indonesia.

Suatu hal yang perlu digaris bawahi ádalah bahwa UU menjamin atau Pemerintah memberikan perlindungan kepada para aktivis serikat pekerja/ serikat buruh untuk tetap melaksanakan aktivitasnya yang positif sepanjang tidak bertentangan dengan UU. Hal ini dengan tegas dijamin oleh: 1) UU Nomor 13/2003 tentang Ketennagakerjaan Pasal 153 ayat (1) huruf $g ; 2$ ) UU Serikat Pekerja/ Serikat Buruh Nomor 21 /2000, Pasal 28 huruf a; dan (3) UU Serikat Pekerja/Serikat Buruh Nomor $21 / 2000$ Pasal 43 ayat (1).

\section{Gaya kepemimpinan}

Pemimpin dalam mencapai suatu tujuan organisasi atau perusahaan masing-masing memiliki gaya untuk mempengaruhi bawahan (anggota) serikat pekerja/serikat buruh mengikuti kehendaknya. Pengertian gaya dalam hal ini merupakan karakteristik pola perilaku, sedangkan gaya kepemimpinan merupakan pola perilaku nyata yang ditunjukkan oleh seseorang dalam kedudukan formal kepemimpinan (Hengst, 1982). Pendapat lainnya, Balanchard (1988) menyatakan bahwa gaya adalah pola-pola perilaku konsisten yang diterapkan dalam bekerja dengan melalui orang lain seperti yang dipersepsikan orang.

Gaya kepemimpinan pada dasarnya memiliki tiga pola dasar yaitu gaya kepemimpinan yang berorientasi pada pelaksanaan tugas, yang mementingkan hubungan kerjasama, dan yang mementingkan hasil yang dapat dicapai. Adapun gaya-gaya kepemimpinan yang pokok atau dapat juga disebut ekstrem, ada tiga yaitu otokratis, demokratis, dan kendali bebas (laissez-faire) (Mullins,1999).

Keberhasilan sebagai pemimpin serikat pekerja/serikat buruh bukan saja karena faktor kepribadian yang dimiliki, akan tetapi dapat disebabkan oleh karena berbagai situasi dan adanya saling hubungan antara pemimpin dengan yang dipimpinnya. Menurut Fiedler yang dikutip oleh Ivancevich (1995) tidak ada gaya kepemimpinan yang cocok untuk semua situasi. Namun, ada tiga faktor situasi kontrol yang perlu dipertimbangkan, yaitu: 1) position power yaitu posisi kekuasaan yang berasal dari organisasi, 2) task 
structure yaitu struktur tugas dan, 3) leadermember relations yaitu hubungan pemimpin dengan bawahan. Posisi kekuasaan ditentukan oleh sejauhmana pemimpin mendapat kepatuhan anak buahnya, dengan menggunakan kekuasaan yang bersumber dari organisasi. Pemimpin yang menerima kekuasaan yang jelas dari organisasi akan mendapat kepatuhan dari bawahan.

Sebagai pemimpin, dalam aktivitasnya tidak terlepas dari penilaian bawahan atau staf (penilaian keatas). Oleh karena itu, penilaian yang diberikan staf tentang perilaku pimpinan serikat pekerja/serikat buruh dalam memimpin organisasinya akan memberikan gambaran gaya kepemimpinannya dalam memimpin organisasi/ perusahaan. Berdasarkan uraian tersebut di atas, gaya kepemimpinan pimpinan serikat pekerja/ serikat buruh dapat dianalogkan dengan adanya perilaku yang ditampilkan oleh pimpinan perserikatan/asosiasi dalam mempengaruhi bawahannya untuk mencapai tujuan organisasi, dalam wujud: 1) pengambilan keputusan; 2) pelimpahan wewenang; 3) memberikan bimbingan dan pengarahan lepada anggota; dan 4) membantu mengatasi konflik antara pekerja/buruh dengan pengusaha.

\section{Etos Kerja}

Salah satu cara pendekatan dalam meningkatkan partisipasi para pekerja/buruh melalui serikat pekerja/serikat buruh adalah menumbuhkan dan membangkitkan etos kerja para pekerja/ buruhnya. Pemahaman etos kerja berangkat dari pengertian etos (ethos). Secara etimologis, terdapat tiga istilah dalam bahasa Inggris, yang mempunyai arti hampir sama, yaitu ethic, ethics dan ethos. Ethic diartikan sebagai standar moral atau nilai-nilai. Ethics sebagai filsafat moral (moral philosophy). Ethos bermakna watak (character). (Webster, 1979)

Etos kerja yang mencerminkan semangat juang tersebut banyak dipengaruihi oleh nilainilai (values) yang dianut oleh seseorang dalam melakukan pekerjaan, sedangkan nilai-nilai itu sendiri selalu berubah dan berkembang. Etos juga merupakan landasan ide, cita-cita, pikiran yang akan menentukan sistem tindakan. Hal ini, karena etos menentukan penilaian seseorang atas suatu pekerjaan, maka ia akan menentukan pula hasil- hasil yang akan dicapai secara kualitatif maupun secara kuantitatif. Hal tersebut sesuai yang dikemukakan Halexandria bahwa etos kerja adalah sifat yang khas (characteristic) semangat seseorang atau kelompok terhadap suatu pekerjaan. (Halexandria, 2004)

Berdasarkan uraian tersebut etos kerja merupakan kesediaan diri seorang pimpinan/ bawahan untuk bekerja dengan baik dalam mencapai tujuan, dengan indikasi: 1) memiliki kedisiplinan dalam melaksanakan tugas; 2 ) bekerjasama dalam melaksanakan tugas; 3 ) bertanggung jawab dalam bekerja; 4) kegairahan dalam bekerja, dan 5) kesesuaian dalam bekerja. Terkait dengan para pemimpin/pengurus Serikat Pekerja/Serikat Buruh yang bukan berasal dari Serikat Pekerja/Serikat Buruh dapat diasumsikan bahwa mereka kurang memiliki etos kerja yang sesuai dengan nilai-nilai dasar perjuangan organisasi tersebut.

\section{Simpulan dan Saran Simpulan}

Dalam upaya mendorong para pekerja/buruh melakukan hubungan industrial dapat dilakukan melalui organisasi atau serikat pekerja/serikat buruh yang telah didirikan di setiap perusahaan/ industri. Organisasi tersebut wajib didaftarkan ke dinas Departemen Tenaga Kerja setempat sesuai dengan peraturan yang berlaku. Para pengurus serikat pekerja/serikat buruh wajib hukumnya berasal dari organisasi serikat pekerja/serikat buruh. Hal ini dimaksudkan agar dalam memperjuangkan hak-hak para pekerja/buruh dapat dilakukan sesuai dengan aspirasi para pekerja/ buruh sesuai prosedur. Suatu hal yang lebih penting lagi adalah bahwa Pengurus serikat pekerja/serikat buruh harus mampu dan mau memberi motivasi para anggotanya untuk berpartisipasi dalam hubungan industrial sesuai dengan bidang keahlian, potensi, dan minat masing-masing. Melalui pembelajaran organisasi (learning organization) diharapkan para pekerja dapat meningkatkan pengetahuan dan keterampilannya sesuai dengan tuntutan dan persyaratan serta karakteristik perusahaan. Partisipasi aktif dan positif para pekerja/buruh dalam berkontribusi pada perusahaan dapat dijadikan sebagai aset/ investasi perusahaan jangka panjang apabila 
para manager mampu mengelola dengan optimal. Hal ini akan berdampak pada peningkatan kinerja atau produktivitas hasil kerja perusahaan.

Ketimpangan sistem perburuhan di Indonesia lebih dikarenakan belum adanya keberpihakan dari yang berwenang (Pemerintah dan Pengusaha) kepada yang lemah (kaum pekerja/buruh) dalam mengimplementasikan hak-hak sebagai pekerja/buruh sesuai dengan UU dan implementasi perlindungan ketenagakerjaan sesuai dengan HAM.

Dalam upaya meningkatkan pengetahuan dan keterampilan di bidang tertentu, ILO menyediakan program kegiatan bagi serikat pekerja/ buruh untuk bersama-sama menjalankan aktivitasnya sesuai dengan kebutuhan masingmasing serikat pekerja/buruh dalam bentuk Diklat maupun workshop dan kegiatan penelitian aplikatif yang relevan dengan ketenagakerjaan/ serikat pekerja/buruh.

\section{Saran}

Untuk mengurangi kekurang harmonisan hubungan kerja antara buruh dan majikan dapat dilakukan melalui ketaat asasan dalam mengikuti aturan perundang-undangan. Di samping itu, telah tiba saatnya para pengurus serikat pekerja/ serikat buruh dipilih dari orang-orang yang berasal dari pekerja/buruh karena pada hakikatnya eksistensi organisasi serikat pekerja/serikat buruh berasal dari pekerja/buruh, oleh pekerja/buruh, dan untuk pekerja/buruh. Dengan demikian, dalam memperjuangkan mencapai kesejahteraan para anggotanya selalu berpihak pada kebutuhan pekerja/buruh.

Dalam hal meningkatkan pengetahuan dan keterampilan pekerja/buruh melalui pendidikan dan pelatihan, hendaknya setiap perusahaan memiliki tanggungjawab moral terhadap kualifikasi pendidikan pekerjanya sehingga diprogramkan suatu pendidikan formal maupun non formal bagi pekerja/buruh, misalnya melalui pemberian kesempatan untuk mengikuti program paket $A$ (setara SD), paket B (setara SMP), dan paket C (setara SMA dan/atau SMK). Untuk itu pihak perusahaan/industri perlu melakukan kerjasama dengan pihak dinas pendidikan setempat untuk mewujudkan program pendidikan yang dapat terjangkau oleh setiap pekerja. Melalui dana sosial CSR (Coorporate Social Responsibility) di setiap perusahaan/industri dapat pula mewujudkannya dengan berbagai program pendidikan (formal) dan pelatihan peningkatan kinerja sesuai kebutuhannya. Idealnya, sistem pendidikan multi entry multi eksit (sistem keluar-masuk) bagi karyawan dapat meminimalis permasalahan kualifikasi pendidikan yang dimiliki oleh setiap pekerja. Dengan meningkatnya kualitas pendidikan bagi setiap pekerja diharapkan partisipasi pekerja dalam industrialisasi dapat tercipta secara harmonis.

\section{Pustaka Acuan}

Anonim, tanpa tahun, Teori Hubungan Industrial, diunduh pada tanggal 27 Oktober 2010

Anonim, tanpa tahun, Organisasi Buruh Internacional (ILO) Biro Pendidikan Pekerja (Actrav): ILO dan Pekerja

Anonim,tanpa tahun, Gabungan Federasai Serikat Pekerja/Serikat Buruh, 20 Februari 2008

Anonim, HDI update 2008 Indonesia, diakses melalui Google tanggal 20 Agustus 2010

Balanchard Kneth and Hersey Paul, 1988. Management of Organization Behavior, (Singapore: Prentice Hall. Inc.

Blog at WordPress.com, Suara Federasi Serikat Pekerja BUMN Bersatu, diunduh pada tanggal 26 September 2010.

Departemen Pendidikan Nasional, 2002, "Laporan Mendiknas" disampaikan pada tanggal 31 Januari 2002

Departemen Pendidikan Nasional, 2003, Undang-Undang Nomor: 20 Tahun 2003 tentang Sistem Pendidikan Nasional

Siswo Wiratno, 2009, Kajian Tanggungjawab Negara dalam Mewujudkan Pendidikan Bermutu, Jurnal Pendidikan, Balitbang-Depdiknas, Jakarta 
Halexandria, Work Ethic, 2004, (http://Halexandria.org/dward 333htm) diunduh pada tanggal 10 Oktober 2010

Hengst Herbert R and William G. Monahan, 1982. Contenporary Educational Administration, (New York: Macmillan Publishing Co., Inc,

http://www. (ppi) (ppiindia), Pentingnya Serikat Buruh

http://www.hukumonline.com/detail.asp?id=18838\&cl=Berita, diakses pada tanggal 26 Oktober 2010.

http://survey07.ituc-csi.Org/getcountry.pnp?IDLang=EN\&IDCountry=IDN\&ID Supp $=\ldots 18 / 10 / 2008$, diunduh pada tanggal 26 Oktober 2010

Ivancevich John M, Donnely James H, Jr. James L. Gibson, 1995, Fundamental of Management, USA: Richard D Irwin, Inc.

Mullins Laury J, 1999. Management and Organizational Behavior, London: Prentice Hall.

Undang-Undang Dasar Negara Republik Indonesia Tahun 1945 (Hasil Revisi Pertama)

Undang-Undang Republik Indonesia Nomor: 13 Tahun 2003 tentang Ketenagakerjaan, Jakarta.

Undang-Undang Republik Indonesia Nomor: 21 Tahun 2000 tentang Serikat Pekerja/Serikat Buruh, Jakarta.

Undang Undang Republik Indonesia Nomor:18 Tahun 1956 tentang Persetujuan Konvensi Organisasi Perburuhan Internasional: Hak untuk berorganisasi dan untuk berunding bersama

Undang-Undang Dasar Republik Indonesia Nomor 39 Tahun 1999 Tentang Hak-Hak Asasi Manusia (HAM)

Undang-Undang Republik Indonesia Tahun 1984 (Ratifikasi Konvensi Penghapusan Segala Bentuk Diskriminasi terhadap perempuan/CEDAW

Undang-Undang Republik Indonesia Nomor 20 Tahun 1999. Ratifikasi konvensi ILO No. 38 Tentang usia minimum yang diperbolehkan bekerja

Webster Noah, 1979, Webster's New Twentieth Century: Dictionary Unabridged, USA: William Collins Publishers. 